\title{
PEMBELAJARAN STATISTIKA MELALUI PROJECT BASED LEARNING DENGAN BANTUAN MICROSOFT EXCEL UNTUK MENINGKATKAN HASIL BELAJAR PESERTA DIDIK VIII D SMPN UNGGULAN SINDANG INDRAMAYU
}

\author{
Eti Herawati \\ SMP Negeri Unggulan Sindang Indramayu, Jalan Raya Sindang KM.3 Indramayu, \\ smpnunggulansindang@gmail.com
}

\begin{abstract}
ABSTRAK
Penelitian ini bertujuan untuk meningkatan hasil belajar peserta didik Kelas VIII D SMP Negeri Unggulan Sindang Kabupaten Indramayu tahun pelajaran 2014/2015 pada materi Statistika melalui Project Based Learning dengan bantuan Microsoft Excel. Subjek penelitian ini adalah peserta didik kelas VIII D SMP Negeri Unggulan Sindang Indramayu tahun pelajaran 2014/2015 berjumlah 30 orang yang terdiri atas 19 orang perempuan dan 11 orang laki-laki. Teknik pengumpulan data dalam penelitian ini menggunakan lembar observasi, tes, observasi, angket, wawancara dan dokumentasi. Sikap terhadap pembelajaran Statistika melalui Project Based Learning dengan bantuan Microsoft Excel sebagian besar sudah baik dan sangat baik. Dapat dilihat persentase jumlah yang berhasil pada siklus I meningkat dari $86,67 \%$ menjadi $100 \%$ pada siklus II.
\end{abstract} Persentase ketuntasan hasil belajar pada kompetensi keterampilan terhadap pembelajaran matematika meningkat. Persentase jumlah yang berhasil siklus I meningkat dari $73 \%$ menjadi $86,67 \%$ di siklus II. Hasil pembelajaran berdasarkan aspek pengetahuan terjadi peningkatan jumlah yang mencapai KKM siklus I ke siklus II. Persentase mencapai KKM pada siklus I 76,67\% meningkat menjadi $86,67 \%$ pada siklus II. Berdasarkan hasil penelitian yang telah dilaksanakan, pembelajaran statistika dengan menggunakan Model Pembelajaran Project Based Learning

\section{ABSTRACT}

The aim of this research is to improve the learning outcomes of VIIID students of SMP Negeri Unggulan Sindang Indramayu school year 2014/2015 on Statistic material through Project Based Learning ModelAided Microsoft Excel. The subjects of this research is VIII D students of SMP Negeri Unggulan Sindang Indramayu school year 2014/2015, consist of 30 students, 19 girls and 11 boys. Data collection techniques in this study using observation sheets, tests, observations, questionnaires, interviews and documentation. Statistics attitude towards learning through Project Based Learning Model-Aided Microsoft Excel mostly been good and very good. Can be seen the percentage of successful the first cycle increased from $86.67 \%$ to $100 \%$ in the second cycle. Percentage mastery learning outcomes in mathematics learning competency skills is increase. The percentage of successful at first cycle increased from $73 \%$ to $86.67 \%$ in the second cycle. Learning outcomes based on knowledge an increasing number of which reached KKM cycle I to cycle II. KKM percentage reached $76.67 \%$ in the first cycle increased to $86.67 \%$ in the second cycle. Based on the research that has been conducted, statistics learning using Project Based Learning Model-Aided Microsoft Excel is able to improve the learning outcomes of class VIIID students of SMP Negeri Unggulan Sindang Indramayu school year 2014/2015. The application of 
dengan bantuan Microsoft Excel mampu meningkatkan hasil belajar peserta didik Kelas VIIID SMP Negeri Unggulan Sindang Kabupaten Indramayu Tahun Pelajaran 2014/2015. Penerapan pembelajaran statistika melalui Project Based Learning dengan bantuan Microsoft Excel sebagai salah satu alternatif model pembelajaran yang dapat diterapkan untuk topik dan mata pelajaran yang lain tetapi dibutuhkan perencanaan yang baik dan pengelolaan waktu yang tepat.

Kata Kunci: Project Based Learning, Microsoft Excel statistical learning using Project Based Learning Model-Aided Microsoft Excel as an alternative model of learning that can be applied to topics and other subjects but required good planning and proper time management.

Keywords: $\begin{aligned} & \text { Project Based Learning, } \\ & \text { Microsoft Excel }\end{aligned}$

\section{How to Cite: Herawati, E. (2017). Pembelajaran Statistika Melalui Project Based Learning dengan Bantuan Microsoft Excel untuk Meningkatkan Hasil Belajar Peserta Didik VIII D SMPN Unggulan Sindang Indramayu. Mathline: Jurnal Matematika dan Pendidikan Matematika, Vol.2, No.1, 29-44.}

\section{PENDAHULUAN}

Pembelajaran matematika di sekolah bertujuan antara lain agar peserta didik memiliki sikap menghargai kegunaan matematika dalam kehidupan. Hal ini ditunjukkan dengan memiliki rasa ingin tahu, perhatian dan minat mempelajari matematika, serta sikap ulet dan percaya diri dalam pemecahan masalah. Kegagalan atau keberhasilan belajar matematika sangat tergantung pada kemampuan dan kesiapan peserta didik untuk mengikuti kegiatan belajar, salah satunya dipengaruhi bagaimana sikap dan minatnya terhadap matematika.

Pengalaman pembelajaran yang bermakna dan menyenangkan dalam belajar matematika akan sangat mempengaruhi kondisi minat belajar peserta didik. Sebagian besar peserta didik masih menganggap matematika adalah mata pelajaran yang menakutkan, Peserta didik menganggap matematika adalah mata pelajaran yang sulit, tak heran jika peserta didik kurang memiliki motivasi dan keinginan untuk mempelajari matematika sehingga menyebabkan prestasi belajar matematika belum menunjukkan hasil yang memuaskan. Hal ini dapat dilihat dari daftar nilai ulangan harian, nilai tugas, nilai tes semester dan nilai ujian akhir nasional yang belum sesuai dengan harapan guru dan peserta didik. 
Sebagai gambaran pada ulangan harian Materi Statistika tahun pelajaran 2013/2014 dalam tabel ketuntasan sebagai berikut berikut:

Tabel 1. Ketuntasan Belajar Tahun Pelajaran 2013/2014

\begin{tabular}{cccccc}
\hline Kelas & IXB & IXC & IXD & IXE & IXF \\
\hline Ketuntasan & $62 \%$ & $63 \%$ & $68 \%$ & $65 \%$ & $69 \%$ \\
\hline
\end{tabular}

Dari tabel di atas, ketuntasan belajar masih jauh di bawah rata-rata. Diduga penyebab timbulnya masalah antara lain: (1) Sebagian peserta didik beranggapan bahwa matematika merupakan mata pelajaran yang tidak menarik, sulit, dan membosankan. Setiap guru menyampaikan materi pembelajaran matematika banyak peserta didik yang acuh tak acuh. Oleh karena itu kewajiban para gurulah untuk menanamkan rasa senang terhadap materi pelajaran matematika dengan memberi rangsangan atau dorongan kepada mereka, (2)Proses pembelajaran matematika kurang kondusif, dalam penyampaian pelajaran matematika hanya menggunakan metode ceramah yang mungkin dianggap oleh para guru adalah metode yang paling praktis, mudah dan efisien, dilaksanakan tanpa persiapan, sehingga peserta didik tidak bisa menerima pembelajaran yang telah diberikan oleh gurunya, yang mengakibatkan hasil belajar matematika tidak sesuai dengan yang diharapkan, (3) Rendahnya hasil belajar matematika peserta didik juga dikarenakan beberapa guru masih sering mengalami kesulitan dalam menanamkan konsep-konsep dasar matematika kepada peserta didik, (4) Kurangnya variasi guru dalam menggunakan model pembelajaran, juga menyebabkan peserta didik kurang bergairah atau kurang semangat dalam menerima pelajaran. Keadaan ini menyebabkan pemahaman konsep peserta didik cenderung menjadi tidak prima yang berujung pada prestasi belajar peserta didik cenderung rendah.

Agar peserta didik mampu menguasai dan memahami teori, konsep dan prinsipprinsip penerapannya, maka konsep-konsep yang menjadi dasar ilmu harus diberikan peserta didik secara benar. Untuk itu diperlukan interaksi mengajar yang baik antara guru dengan peserta didik dalam proses belajar mengajar. Agar terjalin komunikasi dan interaksi yang baik antar guru dengan peserta didik, maka seorang guru harus memperhatikan kesiapan intelektual peserta didik serta pemilihan metode pembelajaran yang tepat dalam proses belajar mengajar. Keberhasilan peserta didik dalam belajar tergantung pada cara penyajian materi pembelajaran, media pembelajaran dan metode mengajar yang digunakan oleh guru pada proses belajar mengajar. 
Salah satu model pembelajaran yang diharapkan dapat meningkatkan hasil belajar adalah menggunakan Model Pembelajaran Berbasis Proyek (Project Based Learning) denganbantuan Microsoft Excel. Model Pembelajaran Berbasis proyek adalah sebuah model pembelajaran yang menggunakan proyek (kegiatan) sebagai inti pembelajaran. Dalam kegiatan ini, peserta didik melakukan eksplorasi, penilaian, interpretasi, dan sintesis informasi untuk memperoleh berbagai hasil belajar baik pengetahuan, keterampilan maupun sikap. Berdasarkan pada latar belakang sebagaiman diuraikan diatas maka masalah yang ingin diteliti adalah sebagai berikut: "Apakah pembelajaran Statistika melalui Project Based Learning dengan bantuan Microsoft Excel dapat meningkatkan hasil belajar peserta didik Kelas VIII D SMP Negeri Unggulan Sindang Kabupaten Indramayu tahun pelajaran 2014/2015".Sedangkan penelitian ini bertujuan untuk mengetahui besarnya peningkatan hasil belajar peserta didik kelas VIII D SMP Negeri Unggulan Sindang Kabupaten Indramayu tahun pelajaran 2014/2015 terhadap pembelajaran Statistika melalui Project Based Learningdengan bantuan Microsoft Excel.

Hanafiah \& Suhana (2009) mengemukakan bahwa Project Based Learning adalah model pembelajaran yang memperkenankan peserta didik untuk bekerja mandiri dalam mengkonstruksi pembelajarannya dan mengkulminasikannya dalam produk nyata. Sedangkan menurut Trianto (2014) Project Based Learning adalah sebuah model pembelajaran yang inovatif, yang menekankan belajar kontekstual melalui kegiatankegiatan yang kompleks. Wena (2009) berpendapat model pembelajaran Project Based Learning adalah model pembelajaran yang memberikan kesempatan kepada guru untuk mengelola pembelajaran dikelas dengan melibatkan kerja projek. Kerja projek merupakan suatu bentuk kerja yang memuat tugas-tugas kompleks berdasarkan kepada pertanyaan dan permasalahan yang sangat menantang dan menuntun peserta didik untuk merancang, memecahkan masalah, membuat keputusan, melakukan kegiatan investigasi, serta memberikan kesempatan peserta didik untuk bekerja secara mandiri. Dari beberapa pendapat dapat disimpulkan bahwa model pembelajaran Project Based Learning merupakan model pembelajaran inovatif yang melibatkan kerja projek dimana peserta didik bekerja secara mandiri dalam mengkonstruksi pembelajarannya dan mengkulminasikannya dalam produk nyata. Dalam kerja projek memuat tugas-tugas kompleks berdasarkan kepada pertanyaan dan permasalahan yang sangat menantang dan menuntun peserta didik untuk merancang, memecahkan masalah, membuat keputusan, 
melakukan kegiatan investigasi, serta memberikan kesempatan peserta didik untuk bekerja secara mandiri.

\section{METODE PENELITIAN}

Penelitian ini dilaksanakan di SMP Negeri Unggulan Sindang Kabupaten Indramayu Jl. Raya Sindang KM 3 Sindang Indramayu. Penelitian dilakukan pada semester ganjil minggu ke dua sampai minggu ke lima bulan November 2014 (tanggal 7 s.d 26 Novemebr 2014). Subjek dalam penelitiian ini adalah peserta didik kelas VIII D tahun pelajaran 2014/2015 yang berjumlah 30 peserta didik yang terdiri dari 19 peserta didik perempuan dan 11 peserta didik laki-laki dengan kemampuan yang heterogen. Kelas tersebut memiliki karakteristik umum seperti kelas-kelas lain pada umumnya.

Penelitian ini merupakan penelitian tindakan kelas (PTK). Prosedur penelitian tindakan berlangsung secara siklis. Secara garis besar terdapat empat tahapan dalam penelitian tindakan, yaitu: (1) Perencanaan, (2) Pelaksanaan, (3) Pengamatan, (4) Refleksi (Arikunto, 1997). Penelitian ini dilaksanakan 2 siklus dan setiap siklus berlangsung tiga kali pertemuan sesuai dengan rencana pelaksanaan pembelajaran.

\section{Siklus 1}

\section{Pertemuan 1}

Pada pertemuan pertama, setelah mendapat penjelasan dari guru tentang model pembelajaran yang digunakan yaitu Project Based Learningdengan bantuan Microsoft Excel peserta didik bersama dengan kelompoknya (melalui diskusi kelas dengan difasilitasi oleh guru) merancang kegiatan dengan tema menentukan jenis kendaraan bermotor apa saja yang akan diamati, berdasarkan banyaknya roda, yaitu roda dua, roda tiga, roda 4 dan roda lebihdari empat. Peserta didik dalam kelompoknya mulai menyusun jadwal yaitu dengan mengamati dan mendata banyaknya kendaraan yang lewat di jalan tertentu dalam waktu tertentu.

Selama satu minggu antara pertemuan 1 dan pertemuan 2 tersebut peserta didik berkonsultasi dengan guru tentang pelaksanaan penyelesaian tugas proyek (monitoring guru) sedangkan pada pertemuan 2 adalah presentasi hasil proyek.

\section{Pertemuan 2}

Pada pertemuan ke dua, data yang sudah dikumpulkan ini kemudian harus disusun dan sajikan dalam bentuk grafik atau diagram yang sesuai dengan diawali dengan membuat tabel distribusi frekuensi. Diagram harus dibuat secara manual dan 
computerize menggunakan aplikasi komputer yang sudah mereka kuasai. Dan terakhir, hasil observasi dan laporannya ini akan dipresentasikan di kelasnya masing-masing.

\section{Pertemuan ke 3}

Pada pertemuan ke tiga, peserta didik diberikan tes siklus I

\section{Siklus 2}

\section{Pertemuan 1}

Dilaksanakan berdasarkan hasil refleksi dari siklus 1. Peserta didik dalam kelompok diberikan tugas projek dengan tema yang berbeda-beda. Adapun tema yang diberikan adalah:
a. Survei jenis pekerjaan di suatu RT;
b. Survei jumlah pengunjung disuatu Puskesmas terdekat dalam enam bulan terakhir;
c. Survei jumlah buku di perpustakaan sekolah;
d. Survei jumlah pengunjung di perpustakaan sekolah dalam enam bulan terakhir;
e. Survei ukuran sepatu teman di kelasnya;
f. Surveilima jenis makanan favorit pada anggota keluarganya.

Selama satu minggu antara pertemuan 1 dan pertemuan 2 tersebut peserta didik berkonsultasi dengan guru tentang pelaksanaan penyelesaian tugas proyek (monitoring guru) sedangkan pada pertemuan 2 adalah presentasi hasil proyek.

\section{Pertemuan 2}

Pada pertemuan ke dua, data yang sudah dikumpulkan ini kemudian harus disusun dan sajikan dalam bentuk grafik atau diagram yang sesuai dengan diawali dengan membuat tabel distribusi frekuensi. Diagram harus dibuat secara manual dan computerize menggunakan aplikasi komputer yang sudah mereka kuasai. Dan terakhir, hasil observasi dan laporannya ini akan dipresentasikan di kelasnya masing-masing.

\section{Pertemuan ke 3}

Pada pertemuan ke tiga, peserta didik diberikan tes siklus II Setelah pertemuan ke 3 peserta didik diberikan angket

Observasi dilaksanakan pada saat KBM berlangsung dengan melibatkan observer atau pengamat yang terdiri dari guru-guru Matematika. Peserta didik yang menjadi pokok 
pengamatan dikelompokan secara heterogen dalam mencapai tujuan pembelajaran agar memudahkan proses penyelesaian tugas projek secara berkelompok.

Pada tahap refleksi data hasil kegiatan observasi dianalisis dan hasilnya dijadikan bahan untuk menyusun perencanaan serta penyesuaian tindakan pada siklus berikutnya. Sedangkan pada tahap refleksi Siklus ke dua dilakukan analisis hasil dan digunakan untuk menarik kesimpulan serta menentukan saran.

Instrumen penelitian yang digunakan dalam penelitian ini mencakup tugas proyek, observasi, angket, wawancara dan dokumentasi.

\section{Teknik Pengumpulan Data}

1. Tugas Proyek

Dalam penilaian proyek ada tiga hal yang perlu dipertimbangkan yaitu:

a. Kemampuan pengelolaan

Kemampuan peserta didik dalam memilih topik, mencari informasi dan mengelola waktu pengumpulan data serta penulisan laporan.

b. Relevansi

Kesesuaian dengan mata pelajaran, dengan mempertimbangkan tahap pengetahuan, pemahaman dan keterampilan dalam pembelajaran.

c. Keaslian

Proyek yang dilakukan peserta didik harus merupakan hasil karyanya, dengan mempertimbangkan kontribusi guru berupa petunjuk dan dukungan terhadap proyek peserta didik.

2. Lembar Observasi

Lembar observasi disusun untuk memperoleh gambaran langsung tentang kondisi pelakasanaan pembelajaran dengan menggunakan model pembelajaran Project Based LearningMicrosoft Excel. Observasi tindakan ini dilaksakan oleh rekan guru serumpun yang bertindak sebagai observer. Lembar observasi disusun untuk mengamati peneliti dalam mengamati tindakan kelas, kondisi kelas, dan keakktifan peserta didik dalam proses pembelajaran

\section{Angket}

Angket dalam penelitian ini digunakan untuk mengukur tanggapan dan sikap siwa setelah pembelajaran. Isi dari angket ini mengenai pendapat peserta didik terhadap kegiatan proses pembelajaran, bahan ajar, metode pembelajaran, dan sikap guru. Dari 
angket ini kita dapat mengetahui tentang respon peserta didik terhadap kegiatan pembelajaran secara keseluruhan.

\section{Wawancara}

Wawancara yang dilakukan oleh peneliti merupakan wawancara terbuka, subjek mengetahui sedang diwawancarai dan mengetahui pula apa maksud wawancara. Tujuan wawancara ini adalah untuk mengetahui pandangan, sikap, dan motivasi peserta didik dalam pembelajaran statistika dengan menggunakan model pembelajaran Project Based Learning berantuan Microsoft excel. Sasaran wawancara adalah 3 orang peserta didik yang nilainya tinggi, sedang dan rendah dalam tes tertulis setiap siklus. Wawancara dilaksanakan di luar jam pelajaran setelah pembelajaran telah selesai.

5. Dokumentasi Foto dan Video

Foto dan video digunakan untuk merekam perilaku (tingkah laku) peserta didik selama pembelajaran berlangsung. Dokumentasi foto dan video dipilih dengan tujuan untu memperkuat hasil penelitian juga untuk menjelaskan keruntutan penelitian dari awal sampai akhir, sehingga penelitian tersebut dapat dipertanggungjawabkan. Hal-hal yang perlu didokumentasikan adalah sebagai berikut: (1) saat guru menyampaikan materi tentang penyajian data dengan menggunakan diagram batang, diagram garis dan diagram lingkaran dengan menggunakan komputer, (2) aktivitas peserta didik dalam proses pembelajaran, (3) aktivitas peserta didik ketika mengerjakan tugas projek, (4) aktivitas peserta didik dalam kegiatan diskusi dan presentasi.

\section{Teknik Analisis Data}

\section{Analisis Data Hasil Pengamatan}

Analisis data aktivitas guru dan peserta didik didasarkan dari hasil lembar pengamatan. Setelah melakukan pengamatan pada pertemuan 1 dan 2 (siklus pertama), pengamat dan peneliti mendiskusikan hasil pengamatan masing-masing pertemuan tersebut dan menganalisisnya dengan melihat kesesuaian tindakan yang dilaksanakan dengan langkah-langkah penerapan model pembelajaran Project Based LearningMicrosoft Excel sehingga akan tampak kekurangan-kekurangan yang dilakukan oleh guru pada siklus pertama. Jika masih ada kelemahan atau tindakan yang belum sesuai dengan langkahlangkah penerapan model pembelajaran Project Based LearningMicrosoft Excel maka perlu direncanakan tindakan baru sebagai usaha perbaikan pada pelaksanaan pembelajaran selanjutnya pada siklus kedua. 


\section{Analisis Data Hasil Belajar Matematika Peserta didik}

Analisis data hasil belajar matematika peserta didik dilakukan menggunakan analisis ketercapaian KKM pada kompetensi sikap, keterampilan, dan pengetahuan.

\section{Analisis Keberhasilan Tindakan}

Menurut Suyanto (1997) apabila keadaan setelah tindakan lebih baik, maka dapat dikatakan bahwa tindakan telah berhasil, akan tetapi apabila tidak ada bedanya atau bahkan lebih buruk, maka tindakan belum berhasil atau telah gagal. Keadaan lebih baik yang dimaksudkan adalah jika terjadi perbaikan proses dan hasil belajar peserta didik setelah penerapan Project Based LearningMicrosoft Excel.

\section{HASIL PENELITIAN DAN PEMBAHASAN}

\section{Deskripsi Hasil Penelitian}

\section{Pelaksanaan Siklus I}

Pada pertemuan pertama, setelah mendapat penjelasan dari guru tentang model pembelajaran yang digunakan yaitu Project Based LearningMicrosoft Excel peserta didik bersama dengan kelompoknya (melalui diskusi kelas dengan difasilitasi oleh guru) merancang kegiatan (menentukan jenis kendaraan bermotor apa saja yang akan diamati, berdasarkan banyaknya roda, yaitu roda dua, roda tiga, roda 4 dan roda lebihdari empat). Peserta didik dalam kelompoknya mulai menyusun jadwal yaitu dengan mengamati dan mendata banyaknya kendaraan yang lewat di jalan tertentu dalam waktu tertentu.

Data yang sudah dikumpulkan ini kemudian harus disusun dan sajikan dalam bentuk grafik atau diagram yang sesuai. Diagram harus dibuat secara manual dan computerize menggunakan aplikasi komputer yang sudah mereka kuasai. Dan terakhir, hasil observasi dan laporannya ini akan dipresentasikan di kelasnya masing-masing. Guru memberikan kebebasan kepada masing-masing kelompok untuk memikirkan teknik atau cara-cara memperoleh data-data itu. Termasuk setelah data itu diperoleh, mereka harus bisa menentukan grafik atau diagram apa yang sesuai untuk menyajikan data yang sudah mereka kumpulkan itu.

Peserta didik tidak sabar untuk memulai kegiatan belajar di luar ruangan. Peserta didik sangat senang sekali mengamati kendaraan bermotor yang lewat, menuliskan jumlah roda dari kendaraan tersebut. Pembuatan diagram batang, diagram garis dan lingkaran dengan menggunakan komputer juga merupakan hal yang baru bagi peserta didik. Peserta didik secara keseluruhan menunjukkan keingintahuan yang besar bagaimana cara membuat 
diagram-diagram tersebut dengan menggunakan Microsoft Excel. Karena baru permulaan mereka masih terlihat bingung disebabkan peserta didik belum memahami betul cara menggunakan program Microsoft Excell. Beberapa peserta didik mengajukan pertanyaan karena tidak memahami perintah pengerjaan. Tetapi ditengah pembelajaran mereka terlihat senang, walau ada beberapa peserta didik yang kelihatan masih belum berpartisipasi. Waktu dirasakan kurang, penyebabnya jumlah komputer di lab komputer tidak sesuai dengan jumlah peserta didik, jadi tidak bisa satu peserta didik satu komputer sedangkan peserta didik ingin mencoba berbagai bentuk diagram dan mewarnainya sesuai dengan selere mereka.

Pada pertemuan kedua guru menanyakan sampai di mana hasil kegiatan dan meminta peserta didik menyelesaikan proyeknya. Peserta didik (dalam satu kelompok) meneruskan mengolah data yang sudah tercatat dalam tabel, dan menyajikannya dalam bentuk diagram batang, diagram garis dan diagram lingkaran dengan menggunakan komputer dengan kecepatan menyelesaikannya yang berbeda-beda. Setiap kelompok (diwakili oleh salah satu anggota kelompok) mempresentasikan hasil projek yang telah mereka peroleh. Peserta didik lain dan guru memberikan tanggapan. Ketika kegiatan presentasasi, peserta didik ada yang tampak masih malu-malu dan takut salah dalam menjawab pertanyaan-pertanyaan yang ada dalam soal. Sementara belum semua peserta didik lain menyimak hasil kelompok yang sedang presentasi karena masih sibuk dengan tugas kelompknya yang belum selesai. Keenam kelompok menyimpulkan banyaknya jumlah kendaraan bermotor menyebabkan tingkat polusi sangat tinggi. Diakibatkan karena banyak anak usia sekolah membawa kendaraan bermotor padahal belum memiliki SIM. Dan merekomendasikan kepada instansi terkait untuk mengadakan razia untuk anak sekolah yang menggunakan motor dan belum memiliki SIM. Diakhir pembelajaran guru menghimbau kepada peserta didik yang memiliki laptop atau netbook untuk membawanya di pertemuan berikutnya.

Untuk mengetahui hasil pembelajaran dan penekanan terhadap materi yang sudah dipelajarinya, peserta didik perlu diberi tugas mandiri secara individu.

Sebelum memulai pertemuan ke 3 dilakukan jajak pendapat. Hasilnya peserta didik menuliskan pembelajaran matematika terasa menyenangkan jika materinya mudah dipahami dan kegiatan pembelajaran dilakukan secara berkelompok dan menggunakan model pembelajaran Project Based Learningdengan bantuan Microsoft Excel. Pembelajaran terasa membosankan jika dilakukan dengan ceramah. 


\section{Pelaksanaan Siklus II}

Pada pertemuan ke empat, guru memberikan tugas proyek yang ke dua dengan tema yang berbeda-beda. Adapun tema yang diberikan adalah:

a. Survei jenis pekerjaan di suatu RT

b. Survei jumlah pengunjung disuatu Puskesmas terdekat dalam enam bulan terakhir

c. Survei jumlah buku di perpustakaan sekolah

d. Survei jumlah pengunjung di perpustakaan sekolah dalam enam bulan terakhir

e. Survei ukuran sepatu teman di kelasnya

f. Survei lima jenis makanan favorit pada anggota keluarganya

Peserta didik bersama dengan kelompoknya (melalui diskusi kelas dengan difasilitasi oleh guru) merancang kegiatan dan menyusun jadwal.

Pada pertemuan ke lima guru menanyakan sampai di mana hasil kegiatan dan meminta peserta didik menyelesaikan proyeknya. Peserta didik (dalam satu kelompok) meneruskan mengolah data yang sudah tercatat dalam tabel, dan menyajikannya dalam bentuk diagram batang, diagram garis dan diagram lingkaran dengan menggunakan komputer.

Terjadi perkembangan yang signifikan tentang keaktifan peserta didik dalam berinteraksi dengan kelompoknya. Kegiatan berlangsung dalam suasana mengasyikkan. Peserta didik terlihat sangat bersemangat, tampak gembira selama mengikuti pembelajaran termasuk ketika melakukan diskusi. Peserta didik aktif berdiskusi, bekerja dalam kelompok, dan mengajukan pertanyaan. Ketakutan peserta didik untuk bertanya kurang karena peneliti banyak memberikan motivasi dan perhatian dengan berkeliling pada setiap kelompok. Diskusi dalam kelompok terlihat lebih hidup. Antar anggota kelompok sudah lebih berani mengungkapkan pendapat. Peserta didik menyadari pentingnya diskusi dalam kelompok. Dengan berdiskusi bersama teman akan menambah wawasan pemahaman peserta didik itu sendiri. Peran teman satu kelompok sangat penting dalam hal menyelesaikan permasalahan. Kegiatan presentasi berjalan cukup baik, peserta didik nampak lebih berani maju kedepan kelas dan lebih berani menjelaskan ide-idenya. Peserta didik nampak semangat ketika mempresentasikan hasil diskusinya, sementara peserta didik yang lain menunjukkan keingintahuan terhadap isi pembicaraan dengan menajukan pertanyaan untuk memperjelas maksud dari pernyataan teman yang sedang presentasi

Kelompok 1 mendapat tugas mengunjungi puskesmas terdekat untuk mendata jumlah pengunjung enam bulan terakhir. Melaporkan data hasil kunjungan ternyata jumlah 
pengunjung mengalami peningkatan dari bulan ke bulan. Dalam satu bulan jumlah pengunjung terbanyak 1.793 orang. Mayoritas adalah anak-anak yang diakibatkan oleh penyakit demam berdarah. Rekomendasi untuk pihak terkait harus sering diadakan penyemprotan untuk mencegah berkembangnya penyakit deman berdarah. Dirumah-rumah penduduk harus dihindari adanya air tergenang di ember, selokan dll yang merupakan tempat berkembangnya jentik-jentik nyamuk demam berdarah.

Kelompok 2 mendapat tugas mengunjungi perpustakaan sekolah dan mendata jumlah pengunjung enam bulan terakhir. Melaporkan data hasil kunjungan ternyata jumlah pengunjung perpustakaan sangat sedikit sekali dan menurun. Ini dampak dari dibolehkannya siswa membawa HP sehingga anak-anak malas untuk berkunjung ke perpustakaan. Kelompok tabung merekomendasikan kepada pihak sekolah ada larangan bagi siswa untuk membawa HP dan sebaiknya guru-guru memberikan tugas kepada siswanya untuk berkunjung ke perpustakaan untuk menyelesaikan tugas-tugas kelompoknya dengan merangkum atau hal lainnya.

Kelompok 3 mendapat tugas mengunjungi perpustakaan sekolah dan mendata jumlah jenis buku yang ada di perpustakaan. Melaporkan data hasil kunjungan ternyata jumlah buku terbanyak adalah buku kurikulum 2013 dan paling sedikit buku non fiksi.

Kelompok 4 mendapat tugas mendata nomor sepatu teman-teman di kelasnya. Melaporkan data hasil surveinya ternyata ada 6 anak yang memiliki ukuran sepatu yang sama yaitu no 37, 38 dan 41, Ukuran sepatu terkecil nomor 36.

Kelompok 5 mendapat tugas mendata lima makanan Favorti anggota keluarga. Melaporkan data hasil sutveynya makanan yang paling disukai adalah dari olahan ayam (ayam bakar dan ayam panggang) dan paling sedikit adalah semur jengkol.

Kelompok 6 mendapat tugas mengunjungi RT terdekat dan mendata jenis pekerjaan warga desanya. Melaporkan data hasil kunjungan ternyata jumlah terbanyak adalah berprofesi sebagai petani dan paling sedikit sebagai TNI/POLRI.

Selama kegiatan pembelajaran, guru memberika perhatian pada peserta didik yang pasif dengan menyebut namanya atau memintanya menyampaikan pendapat. Cara ini berhasil menarik perhatian peserta didik untuk terlibat dalam diskusi. Guru kemudian memberikan pujian bagi peserta didik yang memberikan tanggapan dengan baik. Terjadinya kegiatan tanya jawab antara peserta didik dengan peserta didik maupun peserta didik dengan pendidik menunjukkan bahwa peserta didik berminat terhadap kegiatan belajar. 
Untuk mengetahui hasil pembelajaran dan penekanan terhadap materi yang sudah dipelajarinya, peserta didik perlu diberi tugas mandiri secara individu.

\section{Pembahasan Hasil Penelitian}

Berdasarkan analisis data tentang hasil belajar matematika peserta didik diketahui bahwa terjadi peningkatan jumlah peserta didik yang mencapai KKM pada penilaian sikap, penilaian pengetahuan dan penilaian keterampilan. Hasil pembelajaran berdasarkan aspek sikap diperoleh dari observasi (sikap toleransi dan percaya diri) dan penilaian diri. Presentasi ketercapaian nilai sikap, dapat dilihat pada Tabel 2

Tabel 2. Persentase Ketercapaian Nilai Sikap Peserta Didik

\begin{tabular}{cccc}
\hline \multirow{2}{*}{ Modus } & Prediket & \multicolumn{2}{c}{ Frekuensi Peserta didik } \\
\cline { 2 - 4 } & & Siklus I & Siklus II \\
\hline 4 & SB & 17 & 26 \\
3 & B & 9 & 4 \\
2 & C & 4 & \\
1 & K & & 30 \\
Jumlah peserta didik yang berhasil & Persentase & 26 & 30 \\
\multicolumn{2}{c}{ Pumlah peserta didik } & $86,67 \%$ & $100 \%$ \\
\hline
\end{tabular}

Berdasarkan Tabel 2, terlihat bahwa sikap peserta didik terhadap pembelajaran Statistika dengan menggunakan model Project Based Learningdengan bantuan Microsoft Excel sebagian besar sudah baik dan sangat baik. Dapat dilihat persentase jumlah peserta didik yang berhasil pada siklus I meningkat dari $86,67 \%$ menjadi $100 \%$ pada siklus II. Pada siklus I, terdapat 4 peserta didik yang mendapat nilai $\mathrm{C}$, kemudian peneliti mewawancarainya diluar jam pelajaran. Ternyata peserta didik kurang memahami instrumen pada penilain diri.

Hasil pembelajaran berdasarkan aspek keterampilan diperoleh dari tugas proyek yang pertama yaitu mengamati jumlah kedaraan bermotor yang melewati depan sekolah kemudian hasil pengamatan tersebut dibuat tabel frekuensinya dan dilanjutkan dengan membuat diagram batang, diagram garis dan diagram lingkaran dengan menggunakan komputer (program Microsoft Excel). Sedangkan untuk tugas proyek yang ke dua Peserta didik diberi tugas proyek dengan tema yang berbeda-beda yaitu survei jenis pekerjaan di suatu RT, survei jumlah pengunjung disuatu Puskesmas terdekat dalam enam bulan terakhir, survei jumlah buku di perpustakaan sekolah, survei jumlah pengunjung di perpustakaan sekolah dalam enam bulan terakhir, survei ukuran sepatu teman di kelasnya dan survei lima jenis makanan favorit pada anggota keluarganya. 
Ada tiga tahap yang dinilai yaitu tahap perencanaan (persiapan dan rumusan judul), tahap pelaksanaan (sistematika kegiatan, keakuratan informasi, kuantitas sumber data, analisis data, penarikan kesimpulan) dan tahap pelaporan (performan, penguasaan).

Persentase ketercapaian nilai keterampilan peserta didik pada siklus I dan II dapat dilihat pada Tabel 3 .

Tabel 3. Persentase Ketercapaian Nilai Keterampilan Peserta Didik

\begin{tabular}{cccc}
\hline Skala & Predikat & \multicolumn{2}{c}{ Frekuensi Peserta Didik } \\
\cline { 2 - 4 } & & Siklus I & Siklus II \\
\hline $3,85-4,00$ & $\mathrm{~A}$ & 10 & 15 \\
$3,51-3,84$ & $\mathrm{~A}-$ & 5 & 7 \\
$3,18-3,50$ & $\mathrm{~B}+$ & 5 & 4 \\
$2,85-3,17$ & $\mathrm{~B}$ & 2 & \\
$2,51-2,84$ & $\mathrm{~B}-$ & 8 & 4 \\
$2,18-2,50$ & $\mathrm{C}+$ & & \\
$1,85-2,17$ & $\mathrm{C}$ & & \\
$1,51-1,84$ & $\mathrm{C}-$ & & \\
$1,18-1,50$ & $\mathrm{D}+$ & 30 & 30 \\
$1,00-1,17$ & $\mathrm{D}$ & 6 & 28 \\
\multicolumn{2}{c}{ Jumlah peserta didik } & $73 \%$ & $86,67 \%$ \\
Jumlah peserta didik yang tuntas & Persentase & & \\
\hline
\end{tabular}

Berdasarkan Tabel 3, terlihat bahwa persentase ketuntasan hasil belajar pada kompetensi keterampilan peserta didik terhadap pembelajaran matematika meningkat. Persentase jumlah peserta didik yang berhasil siklus I meningkat dari 73\% menjadi $86,67 \%$ di siklus II. Pada siklus I ada 8 peserta didik yang mendapat nilai B-. Kemudian peneliti mewawancarai ke dua kelompok tersebut diluar jam pelajaran. Ternyata mereka belum memahami program microsoft excel, juga belum memahami cara membuat laporan suatu projek. Bahkan ada salah satu peserta didik yang bertanya "bu, di laptop saya tidak ada Excelnya". Setelah itu peneliti menjelaskan kembali tentang cara membuat diagram batang, diagram garis dan diagram lingkaran dengan menggunakan microsoft excel dan peserta didik diarahkan untuk mampu merepresentasikan diagram tersebut.

Persentase ketercapaian nilai pengetahuan peserta didik pada siklus I dan siklus II dapat dilihat pada Tabel 4. Terjadi peningkatan jumlah peserta didik yang mencapai KKM siklus I ke siklus II. Persentase peserta didik mencapai KKM pada siklus I 76,67\% meningkat menjadi $86,67 \%$ pada siklus II. 
Tabel 4. Persentase Ketercapaian Nilai Pengetahuan Peserta Didik

\begin{tabular}{cccc}
\hline Skala & Prediket & \multicolumn{2}{c}{ Frekuensi Peserta didik } \\
\cline { 2 - 4 } & & Siklus I & Siklus II \\
\hline $3,85-4,00$ & $\mathrm{~A}$ & 6 & 8 \\
$3,51-3,84$ & $\mathrm{~A}-$ & 12 & 13 \\
$3,18-3,50$ & $\mathrm{~B}+$ & & \\
$2,85-3,17$ & $\mathrm{~B}$ & 5 & 4 \\
$2,51-2,84$ & $\mathrm{~B}-$ & 1 & 1 \\
$2,18-2,50$ & $\mathrm{C}+$ & 3 & 3 \\
$1,85-2,17$ & $\mathrm{C}$ & 3 & \\
$1,51-1,84$ & $\mathrm{C}-$ & & \\
$1,18-1,50$ & $\mathrm{D}+$ & & 30 \\
$1,00-1,17$ & $\mathrm{D}$ & 30 & \\
\multicolumn{2}{c}{ Jumlah peserta didik } & 23 & $86,67 \%$ \\
Jumlah peserta didik yang tuntas & Persentase & $76,67 \%$ & \\
\hline
\end{tabular}

Pada siklus I terdapat tujuh pesertadidik dengan nilai di bawah KKM. Kemudian peneliti mewawancarai ke tujuh anak tersebut diluar jam pelajaran. Ternyata mereka belum memahami cara membaca diagram dan merepresentasikannya Setelah itu peneliti menjelaskan kembali tentang cara membaca batang dan peserta didik diarahkan untuk mampu merepresentasikan diagram tersebut. Pada siklus II masih ada empat peserta didik dengan nilai di bawah KKM, kemudain peserta didik diberikan remedial Teaching setelah pulang sekolah.

Dari hasil angket peserta didik menunjukkan sebagian besar peserta didik sangat setuju bahwa pembelajaran matematika dengan menggunakan model Project Based Learningdenganbantuan Microsoft Excel adalah menarik.

Observasi yang dilakukan selama pembelajaran berlangsung ini sebagai upaya dalam mengamati pelaksanaan tindakan. Dalam melakukan observasi, peneliti dibantu kolaborator yang turut dalam mengamati jalannya pembelajaran berdasarkan lembar obeservasi keaktifan peserta didik yang telah disiapkan oleh peneliti. Observasi dilakukan 
untuk melihat proses pembelajaran, sehingga diharapkan akan diperoleh informasi mengenai gambaran pembelajaran yang telah dilaksanakan. Dari hasil observasi pada umumnya pembelajaran tidak menyimpang dari lembar observasi.

\section{KESIMPULAN}

Berdasarkan hasil penelitian yang telah dilaksanakan, pada pembelajaran statistika melalui Project Based Learning denganbatuan Microsoft Excel mampu meningkatkan hasil belajar peserta didik Kelas VIII D SMP Negeri Unggulan Sindang Kabupaten Indramayu Tahun Pelajaran 2014/2015.

Berdasarkan penelitian yang telah dilaksanakan, peneliti mempunyai beberapa saran sebagai berikut:

1. Penerapan pembelajaran statistika melalui Project Based Learning dengan bantuan Microsoft Excel sebagai salah satu alternatif model pembelajaran yang dapat diterapkan untuk topik dan mata pelajaran yang lain

2. Penerapan pembelajaran matematika melalui Project Based Learning dengan bantuan Microsoft Excel dibutuhkan perencanaan yang baik dan pengelolaan waktu yang tepat. Apabila tidak terbimbing dengan baik akan mengakibatkan lambatnya proses pembelajaran sehingga waktu yang direncanakan dalam RPP tidak tepat.

\section{DAFTAR PUSTAKA}

Arikunto, Suharsimi. (1997). Penelitian Tindakan Kelas. Jakarta: Bumi Aksara.

Hanafiah, N \& Suhana, C. (2009). Konsep strategi pembelajaran. Bandung: PT. Refika Aditama.

Trianto. (2014). Mendesain model pembelajaran inovatif, progresif, dan kontekstual. Jakarta: Prenadamedia Group.

Wena, M. (2009). Strategi pembelajaran inovatif kontemporer: suatu tinjauan konseptual operasional. Jakarta: Bumi Aksara. 